\title{
Studi Laju Perubahan Garis Pantai di Pesisir Tenggara Bali Menggunakan Citra Satelit Landsat (Studi Kasus Kabupaten Gianyar dan Klungkung)
}

\author{
I Nengah Jaya Nugraha ab, I Wayan Gede Astawa Karang ab*, \\ I Gusti Bagus Sila Dharma ab \\ a Program Studi Ilmu Kelautan, Fakultas Kelautan dan Perikanan, Universitas Udayana, Kampus UNUD Bukit Jimbaran, Bali 80361, Indonesia \\ ${ }^{b}$ Laboratorium Sistem Informasi Geografis dan Remote Sensing, Fakultas Kelautan dan Perikanan, Universitas Udayana, Bali 80361, Indonesia \\ * Penulis koresponden. Tel.: +6281-933-007-822 \\ Alamat e-mail: gedekarang@unud.ac.id
}

Diterima (received) 28 Agustus 2016; disetujui (accepted) 4 Agustus 2017; tersedia secara online (available online) 8 Agustus 2017

\begin{abstract}
Erosion and abrasion are the events that led to the beach shoreline position changes. The impact of climate change is the rise in sea level also causes changes in the coastline. South East coast of Bali, especially along the coast Gianyar and Klungkung changing coastline. This study aims to identify and calculate the rate of shoreline change in Gianyar and Klungkung from 1995 to 2015. The study was a preliminary information shoreline change and do not analyze the causes such as tides, currents, waves, and wind. The method used remote sensing analysis with the extraction of the coastline from the Landsat 5 satellite images in 1995, Landsat 7 in 2005, and Landsat 8 2015. Landsat imagery analyzed by a combination of methods approach the threshold and band ratio of wave infrared and green. Image processing using software Quantum GIS 2.8 and System for Automated Geoscientific Analyses (SAGA) GIS 2.2, extention Digintal Shoreline Analysis System (DSAS) to make calculations transect coastline. The results of the analysis of overlaying identify coastline in Gianyar and Klungkung change at a rate that varies every village. The rate of change of coastline in Gianyar due to accretion between $0.5096-8.6074 \mathrm{~m} / \mathrm{yr}$, while due to erosion between -3.7343 to $-1.3201 \mathrm{~m} / \mathrm{yr}$. The rate of change in Klungkung regency coastline due to accretion between $0.6337-2.6875 \mathrm{~m} / \mathrm{yr}$, while due to erosion between -8.8795 to $-0.8833 \mathrm{~m} / \mathrm{yr}$.
\end{abstract}

Keywords: rate of shoreline change; Landsat; erosion and acresion

\begin{abstract}
Abstrak
Erosi dan abrasi adalah peristiwa di pantai yang menyebabkan posisi garis pantai mengalami perubahan. Dampak dari perubahan iklim yakni kenaikan tinggi muka air laut juga menyebabkan perubahan garis pantai. Pesisir Tenggara Bali khususnya sepanjang pantai Kabupaten Gianyar dan Klungkung mengalami perubahan garis pantai. Penelitian ini bertujuan untuk mengidentifikasi dan menghitung laju perubahan garis pantai di Gianyar dan Klungkung dari tahun 1995 sampai 2015. Penelitian ini sebagai informasi awal perubahan garis pantai dan tidak menganalisis faktor penyebabnya seperti pasang surut, arus, gelombang, dan angin. Metode yang digunakan adalah analisis penginderaan jauh dengan ekstraksi garis pantai dari citra satelit Landsat 5 tahun 1995, Landsat 7 tahun 2005, dan Landsat 8 tahun 2015. Citra Landsat dianalisis dengan pendekatan kombinasi metode threshold dan band ratio dari gelombang inframerah dan gelombang hijau. Pengolahan citra menggunakan software Quantum GIS 2.8 dan System for Automated Geoscientific Analyses (SAGA) GIS 2.2, extention Digintal Shoreline Analysis System (DSAS) untuk membuat transek perhitungan garis pantai. Hasil analisis tumpang susun mengidentifikasi garis Pantai di kabupaten Gianyar dan Klungkung mengalami perubahan dengan laju yang berbeda-beda setiap desa. Laju perubahan garis pantai di kabupaten Gianyar akibat akresi diantara 0.5096 - $8.6074 \mathrm{~m} / \mathrm{th}$, sedangakn akibat akresi diantara -3.7343 sampai $1.3201 \mathrm{~m} / \mathrm{th}$. Laju perubahan garis pantan di Kabupaten Klungkung akibat akresi diantara $0.6337-2.6875 \mathrm{~m} / \mathrm{th}$, sedangkan akibat erosi diantara -8.8795 sampai $-0.8833 \mathrm{~m} /$ th.
\end{abstract}

Kata Kunci: laju perubahan garis pantai; Landsat; erosi dan akresi 


\section{Pendahuluan}

Perairan pesisir merupakan laut yang berbatasan dengan daratan meliputi perairan sejauh 12 (dua belas) mil laut diukur dari garis pantai, perairan yang menghubungkan pantai dan pulau-pulau, estuari, teluk, perairan dangkal, rawa payau, dan laguna (Kementerian Kelautan dan Perikanan, 2014). Perairan pesisir merupakan zona yang sangat dinamis. Dinamika di pesisir dipengaruhi oleh faktor oseanografi diantaranya gelombang, angin, arus. Dampak dari adanya dinamika pesisir adalah proses erosi dan abrasi. Berdasarkan Peraturan Rencana Pembangunan Jangka Panjang Daerah (RPJPD) Bali Nomor 6 Tahun 2009 (pemprov Bali, 2009) terjadi erosi di beberapa daerah di pesisir Bali pada tahun 1987, 1997, 2003, dan 2004 berturut-turut sepanjang $51.50 \mathrm{~km}, 64.65$ $\mathrm{km}, 70.11 \mathrm{~km}$ dan $89.29 \mathrm{~km}$ atau $20,73 \%$ dari total panjang pantai di Bali.

Selain erosi dan abrasi, kenaikan tinggi muka air laut juga menyebabkan perubahan posisi garis pantai. Kenaikan tinggi muka air laut rata-rata global adalah $1.5(1.3-1.7) \mathrm{mm} /$ th tahun 1901 sampai 1990, dan mengalami meningkatan sebesar $3.2(2.8$ - 3.6) mm/th tahun 1993 sampai 2010 (Gregory, 2013). Kenaikan tinggi muka air laut global disebabkan oleh ekspansi termal air laut, adanya glasier, mencairnya es di antartika dan kutub, berkurangnya cadangan air di daratan (Church et al., 2013). Kenaikan muka laut secara global tentunya berdampak pada Indonesia dan pulau Bali pada khususnya. Erosi, abrasi, dan tinggi muka air laut diasumsikan dapat mempengaruhi posisi garis pantai setiap saat.

Garis pantai adalah batas wilayah daratan yang berbatasan langsung dengan lautan. Garis pantai dapat diidentifikasi ketika batas air laut pada waktu pasang tertinggi telah mencapai daratan (Tarigan, 2007). Mendeteksi perubahan garis pantai membutuhkan pengambilan sampel setiap 10-20 tahun untuk mendapatkan perubahan dalam hitungan sentimeter hingga beberapa puluh meter (Boak and Turner, 2005). Metode yang dapat diterapkan untuk mengidentifikasi perubahan garis pantai adalah metode oneline model, penginderaan jauh, dan menggunakan perangkat lunak tertentu.

Penelitian yang pernah dilakukan di beberapa tempat di daerah Bali yakni menganalisa perubahan garis pantai di Tulamben dengan
Landsat dengan hasil terjadi abrasi di Kubu, Karangasem sejauh $0.68 \mathrm{~m} /$ th dan akresi di Penuktukan, Buleleng sejauh $1.21 \mathrm{~m} /$ th (Putra dkk., 2014); Prediksi perubahan garis pantaai di Nusa Dua dengan One-line Model menghasilkan terjadi erosi ujung pemecah gelombang (Purnaditya et al, 2007); dan analisa perubahan garis pantai Jasri, Karangasem dengan oneline model dengan hasil terjadi erosi disepanjang pantai tersebut (Hidayah dan Dwito, 2012).

Penelitian ini menggunakan citra satelit Landsat TM dan Landsat OLI/TIRS. Landsat memiliki beberapa keunggulan yakni memiliki resolusi spasial 30×30 meter, digunakan oleh banyak peneliti untuk menganalisis garis pantai seperti oleh Hereher (2011), Kaliraj et al. (2015), Ottinger et al. (2015), dan Fraser et al. (2011). Selain itu, citra Landsat juga tersedia dari tahun 1972 hingga saat ini dan diperoleh secara gratis (Hansen and Loveland, 2012).

Objek penelitian ini adalah Pantai sepanjang Kabupaten Gianyar dan Klungkung dengan batas administrasi kabupaten sebagai batas objek penelitian. Pantai sepanjang Kabupaten Gianyar dan Klungkung diperkirakan mengalami proses erosi ataupun akresi berdasarkan laporan dari beberapa media lokal. Kabupaten Klungkung yang mengalami pengikisan pantai sampai 10-15 meter dari garis pantai sebelumnya yang diakibatkan tingginya gelombang pantai selatan (Arthayasa, 2014), Bencana erosi dan abrasi ini juga terjadi di Gianyar yang diperkirakan sepanjang 18 kilometer (Wihardandi, 2012).

Tujuan dari penelitian ini adalah melakukan identifikasi dan menganalisis laju perubahan garis pantai sepanjang Kabupaten Gianyar dan Klungkung. Penelitian ini tidak menganalisa faktor oseanografi pantai seperti pasang surut, gelombang, arus,dan angin sebagai faktor perubahan garis pantai.

\section{Metode Penelitian}

\subsection{Waktu dan Lokasi Penelitian}

Penelitian dilakukan dari bulan Januari 2016 sampai Juni 2016. Studi kasus penelitian sepanjang pantai Kabupaten Gianyar dan Klungkung dengan titik koordinat $8^{\circ} 39^{\prime} 0.28^{\prime \prime}$ LS, $115^{\circ} 16^{\prime} 29.52^{\prime \prime}$ BT sampai pada $8^{\circ} 33^{\prime} 3.26^{\prime \prime}$ LS, $115^{\circ} 28^{\prime} 45.15^{\prime \prime}$ BT. Analisis data dilakukang di Laboratorium 


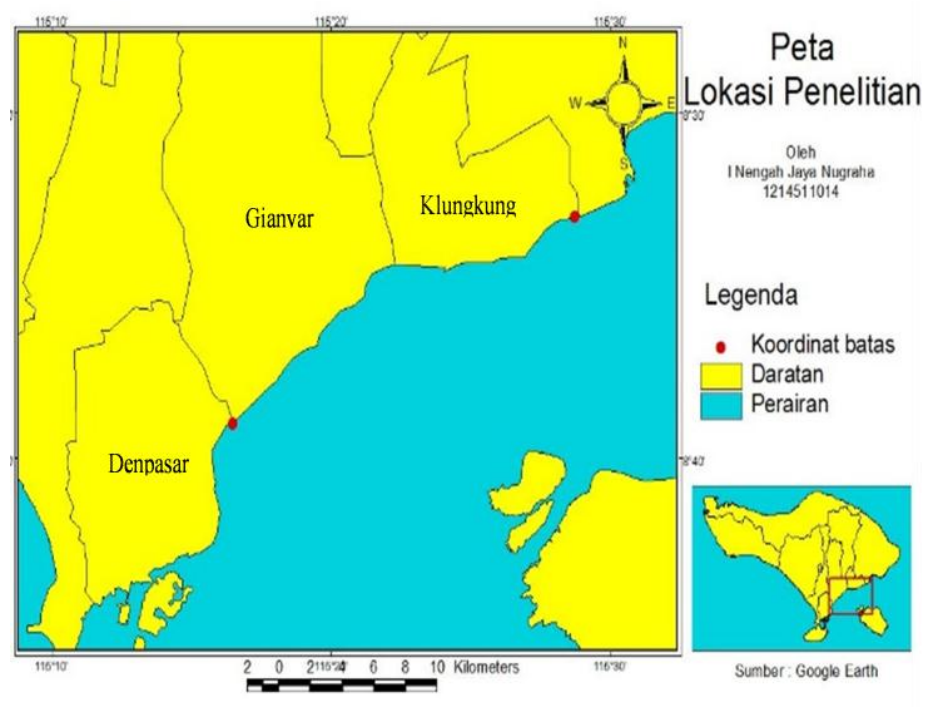

Gambar 1. Peta Penelitian

Penginderaan Jauh dan Sistem Informasi Geografis, Fakultas Kelautan dan Perikanan Universitas Udayana. Peta penelitian ditunjukkan oleh Gambar 1.

\subsection{Alat dan Data}

Alat yang digunakan dalam penelitian ini adalah:

- Personal Computer (PC) digunakan untuk penyelesaian penelitian.

- Software SAGA GIS untuk mengolah citra

- Quantum GIS 2.8 untuk pengolahan vektor

- Digital Shoreline Analysis System (DSAS) untuk membuat transek perhitungan laju perubahan garis pantai

Data yang digunakan adalah Citra satelit Landsat dengan spesisifikasi ditunjukkan oleh Tabel 1.

Tabel 1

Spesifikasi Citra Satelit Landsat

\begin{tabular}{lccc}
\hline \multicolumn{1}{c}{ Citra Landsat } & Tanggal Akuisisi & Path & Row \\
\hline Landsat OLI/TIRS & 9 November 2015 & 116 & 66 \\
Landsat ETM + & 27 April 2005 & 116 & 66 \\
Landsat TM & 26 Mei 1995 & 116 & 66 \\
\hline
\end{tabular}

\subsection{Pengolahan Citra}

Pengolahan citra Landsat meliputi pemotongan citra (Cropping), korekksi radiometrik dan geometrik, thresholding, band ratio, supervised classification.

\subsubsection{Pemotongan Citra (Cropping)}

Pemotongan citra bertujuan untuk mendapatkan membatasi daerah penelitian sesuai dengan kebutuhan. Pada penelitian ini koordinat batas administrasi Kabupaten Gianyar dan Klungkung digunakan sebagai batas penelitian.

\subsubsection{Koreksi Radiometrik dan Geometrik}

Nilai digital dari masing-masing piksel citra diubah menjadi nilai radian dan reflektan dengan algoritma ditunjukan oleh persamaan 1 dan 2 untuk Landsat 5 dan 7, persamaan 3 dan 4 untuk Landsat 8 (Roy et al., 2014).

$$
L_{\lambda}=\left(\operatorname{Gain}_{\lambda} \cdot Q_{c a l}\right)+\operatorname{bias}_{\lambda}
$$

Keterangan:

$L_{\lambda} \quad=$ radian spektral $\left(\right.$ Watts $\left./\left(\mathrm{m}^{2 *} \mathrm{sr}^{*} \mu \mathrm{m}\right)\right)$

$Q_{\text {cal }}=$ nilai piksel $(\mathrm{DN})$

Gain $_{\lambda}=$ gain band specific numbers

bias $_{\lambda}=$ bias band spesific numbers

$$
\rho_{\lambda}=\pi L_{\lambda} d_{s}^{2} /\left(E_{0 \lambda} \cdot \cos (\theta)\right)
$$

Keterangan:

$$
\begin{aligned}
p_{\lambda}= & \text { reflektan spektral }\left(\text { Watts } /\left(\mathrm{m}^{2 *} \mathrm{sr}^{*} \mu \mathrm{m}\right)\right) \\
d_{s}^{2}= & \text { jarak bumi matahari dalam satuan } \\
& \text { astronomi } \\
E_{0 \lambda}= & \text { solar spectral Irradiances (Watts } /\left(\mathrm{m}^{2 *} \mu \mathrm{m}\right) \\
\theta \quad= & \text { Solar elevation angle } \\
L_{\lambda}= & M_{L} Q_{c a l}+A_{L}
\end{aligned}
$$


Keterangan:

$M_{L} \quad=$ konstanta rescalling (radiance_mult_band_x)

$A_{L} \quad=$ konstanta penambah (radiance_add_band_x)

$$
\rho_{\lambda}=M_{p} Q_{c a l}+A_{p}
$$

Keterangan

$$
\begin{aligned}
M_{p}= & \text { konstanta rescalling } \\
& (\text { reflectance_mult_band_x }) \\
A_{p} \quad= & \text { konstanta penambah } \\
& (\text { reflectance_add_band_x })
\end{aligned}
$$

\subsubsection{Tresholding}

Pemisahan daratan dan lautan menggunakan nilai ambang batas dari band 5 pada Landsat TM dan ETM+, serta band 6 pada Landsat OLI/TIRS. Gelombang mid-infrared (SWIR-1) band 5 Landsat TM dan ETM+ dan band 6 Landsat OLI/TIRS merupakan band yang paling tepat untuk ekstrak daratan dan lautan (Kelley et al, 1998).

\subsubsection{Band Ratio}

Pendekan rasio band digunakan untuk menyempurnakan pendekatan treshold yang tidak akurat memisahkan darat dan laut untuk pantai lumpur dan bervegetasi. Panjang gelombang yang digunakan adalah inframerah dekat (near-infrared), gelombang hijau, inframerah pendek (SWIR-1). Rasio band Near infrared dengan band hijau (b2/b4 pada Landsat TM dan ETM+; b3/b5 pada Landsat OLI/TIRS), menghasilkan batas darat-air pada daerah pantai yang tertutup oleh vegetasi. Sedangkan rasio band SWIR-1 dengan band hijau (b2/b5 pada Landsat TM dan ETM+; b3/b6 pada Landsat OLI/TIRS) diperoleh garis pantai dari daerah yang tertutup oleh lumpur (Alesheikh et al, 2007).

\subsubsection{Supervised Classification}

Pemisahan daratan dan lautan menggunakan nilai ambang batas dari band 5 pada Landsat TM dan ETM+, serta band 6 pada Landsat OLI/TIRS. Gelombang mid-infrared (SWIR-1) band 5 Landsat TM dan ETM+ dan band 6 Landsat OLI/TIRS merupakan band yang paling tepat untuk ekstrak daratan dan lautan (Kelley et al, 1998).

\subsubsection{Tumpang Susun antar Citra Landsat}

Garis pantai dalam bentuk vektor hasil klasifikasi tiumpang susun (overley) berurutan dari garis pantai citra Lansat tahun 1995, 2005, dan 2015. Tujuan dari tumpang susun ini untuk

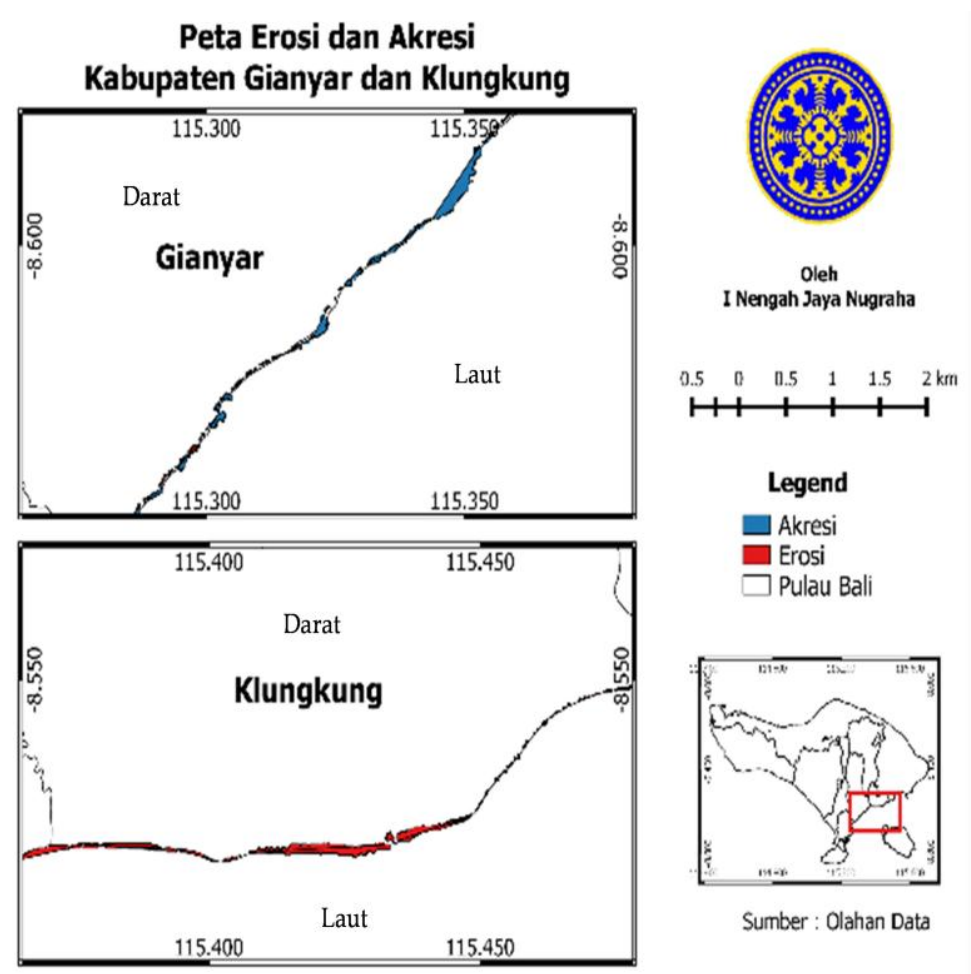

Gambar 2. Peta Analisis Tumpang Susun 
mengidentifikasi perubahan garis pantai yang terjadi.

\subsection{Perhitungan Laju Perubahan Garis Pantai}

Perhitugan laju perubahan garis pantai menggunakan bantuan extention Digital Shoreline Analysis Sistem (DSAS 4.3) untuk membuat transek pengukuran laju. Transek dibuat dengan panjang 1000 meter sedangkan jarak antar transek 50 meter. Transek yang dibuat berdasarkan garis bantu baseline yang arah dan bentuknya mengikuti vektor garis pantai. Panjang transek yang memotong diantara dua vektor garis pantai dinyatakan sebagai perubahan jarak antar garis pantai. Statistik yang digunakan adalah End Point Rate (EPR), menghitung laju perubahan garis pantai dari waktu terdahulu hingga waktu terbaru. Laju perubahan garis pantai dihitung dengan membagi jarak perubahan garis pantai dengan rentan waktu perubahan garis pantai tersebut.

\section{Hasil dan Pembahasan}

Pengukuran jarak antar garis pantai juga menggunakan metode transek dengan jarak antar transek 50 meter dan panjang transek 1000 meter untuk mengantisipasi garis pantai yang tidak berpotongan. Transek yang dibuat mengikuti kontur dari garis pantai sepanjang Gianyar dan Klungkung. Jarak garis pantai dihitung dengan mengetahui panjang transek dari titik perpotongan garis pantai satu dengan garis pantai lainnya. Identifikasi perubahan garis pantai mempertimbangkan kejadian erosi dan akresi, apabila terjadi erosi dari garis pantai tahun awal ke tahun berikutnya maka jarak diberi nilai negatif (-) sedangkan apabila terjadi penambahan daratan atau akresi maka jarak garis pantai diberi nilai positif (+). Tujuan dari pemberian nilai positif dan negatif tersebut adalah untuk memudahkan dalam identifikasi serta laju perubahan garis pantai.

Identifikasi perubahan garis pantai dilakukan dengan analisis tumpang susun antar citra Landsat TM tahun 1995, Landsat TM+ tahun 2005, dan Landsat OLI tahun 2015. Hasil analisis (Gambar 2) tumpang susun menunjukkan adanya perbedaan perubahan garis pantai yang terjadi antara Kabupaten Gianyar dan Klungkung. Perubahan garis pantai yang terjadi di kabupaten Gianyar cenderung mengalami akresi atau penumpukan material di garis pantai. Sedangkan, perubahan garis pantai di Kabupaten Klungkung cenderung mengalami erosi.

Hasil analisis tumpang susun garis pantai (Gambar 2) menunjukkan adanya perubahan garis pantai dari tahun 1995 sampai tahun 2015. Perubahan garis pantai akibat dari adanya akresi terlihat dominan terjadi di pesisir Kabupaten Gianyar (ditunjukkan oleh warna biru pada Gambar 2). Perubahan garis pantai akibat erosi di Kabupaten Gianyar terjadi mendekati perbatasan dengan Kabupaten Klungkung (ditunjukkan oleh warna merah pada Gambar 34). Perubahan garis pantai di Kabupaten Klungkung berbeda dengan di Kabupaten Gianyar yang didominasi oleh erosi (warna merah pada Gambar 2). Sepanjang pantai di Kabupaten Klungkung yang paling luas mengalami erosi terdapat di desa Takmung dan Jumpai.

Laju perubahan garis pantai setiap transek di Desa Batubulan yang ditunjukkan oleh Gambar 3. didominasi oleh adanya akresi. Akresi terjadi dari transek ke-1 sampai ke-10 dan transek ke-12 sampai ke-18 dengan laju akresi tertinggi terjadi pada transek ke-8 sebesar $4.32435 \mathrm{~m} / \mathrm{th}$. Erosi hanya terjadi di transek ke-11 dengan laju erosi $2.0985 \mathrm{~m} / \mathrm{th}$.

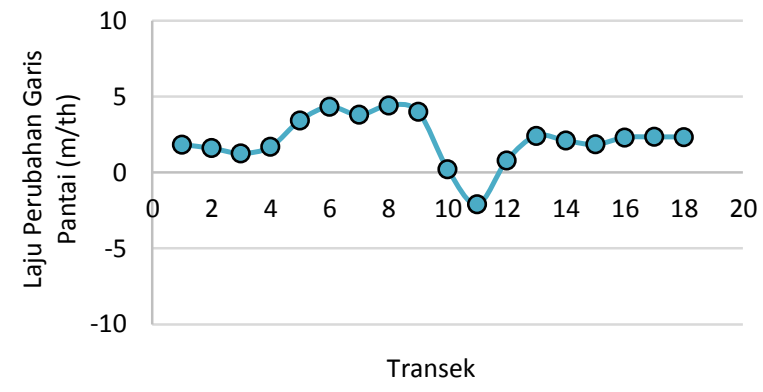

Gambar 3. Laju perubahan garis pantai di Desa Batubulan

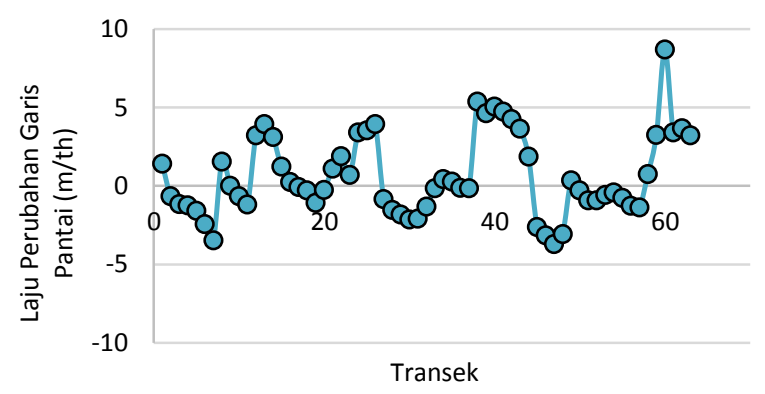

Gambar 4. Laju perubahan garis pantai di Desa Ketewel 
Laju perubahan garis pantai setiap transek di Desa Ketewel yang ditunjukkan oleh Gambar 4 adanya keseimbangan dinamik antara akresi dan erosi. Perubahan garis pantai akibat erosi terjadi di 34 transek dan akibat akresi terjadi di 29 transek. Laju erosi tertinggi terjadi di transek ke-47 dengan $3.7343 \mathrm{~m} / \mathrm{th}$, sedangkan laju akresi tertinggi terjadi di transek ke-60 dengan $8.6968 \mathrm{~m} / \mathrm{th}$.

Laju perubahan garis pantai di Desa sukawati pada Gambar 5 menunjukkan adanya perubahan akresi dan erosi. Akresi terjadi di beberapa transek yakni transek ke-1 sampai ke-18 dan transek ke-33 sampai ke-35, serta transek ke-37 sampai ke-38. Laju akresi tertinggi terjadi di transek ke-8 sebesar $6.08775 \mathrm{~m} / \mathrm{th}$. Erosi terjadi di transek ke-19 sampai ke-32 dan transek ke-36. Laju erosi tertinggi terjadi di transek ke-28 sebesar $1.37125 \mathrm{~m} / \mathrm{th}$.

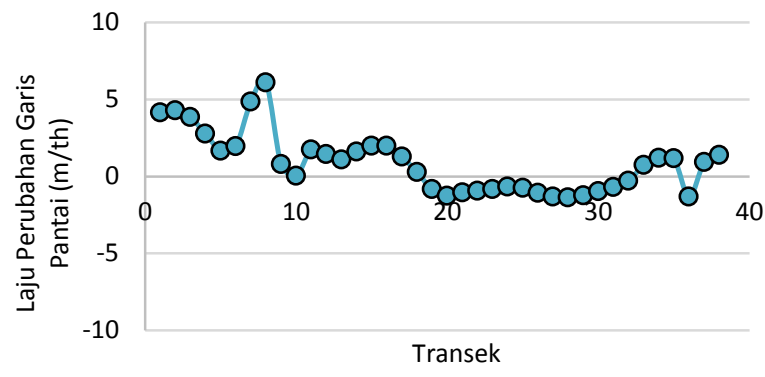

Gambar 5. Laju perubahan garis pantai di Desa Sukawati

Laju perubahan garis pantai di Desa Saba seperti pada Gambar 6 didominasi oleh adanya akresi. Akresi terjadi di transek ke-1 sampe ke-20, sedangkan transek ke-21 dan ke-22 mengalami erosi. Laju akresi tertinggi terjadi di transek ke-17 sebesar $7.3343 \mathrm{~m} /$ th. Laju erosi di transek ke-21 adalah $0.3739 \mathrm{~m} / \mathrm{th}$ dan di transek ke-22 adalah $1.22495 \mathrm{~m} / \mathrm{th}$.

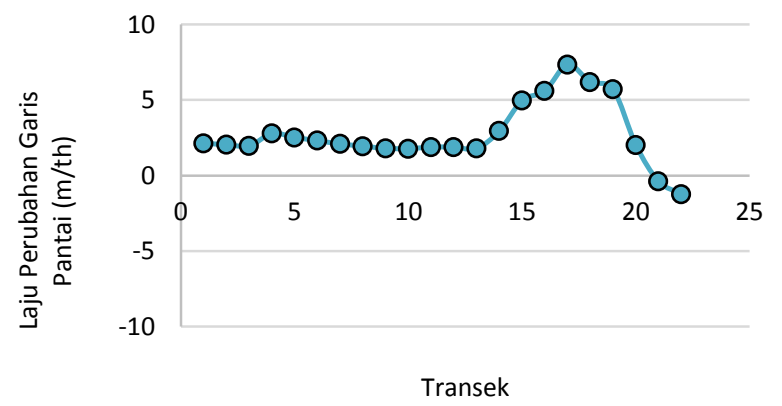

Gambar 6. Laju perubahan garis pantai di Desa Saba

Laju perubahan garis pantai di Desa Pering yang ditunjukkan Gambar 7, ada beberapa transek yang mengalami erosi yaitu transek ke-1 sampai ke-3, transek ke-8 dan ke-9, transek ke-11 serta transek ke-21 sampai ke-23, sedangkan 15 transek lainnya mengalami akresi. Laju erosi tertinggi terjadi di transek ke-1 sebesar $1.3201 \mathrm{~m} / \mathrm{th}$ sedangkan laju akresi tertinggi terdapat di transek ke-20 sebesar $3.80455 \mathrm{~m} / \mathrm{th}$. Transek ke-2 dan ke-3 yang menunjukkan laju perubahan akibat erosi sebesar 0.1384-0.7.557 $\mathrm{m} / \mathrm{th}$.

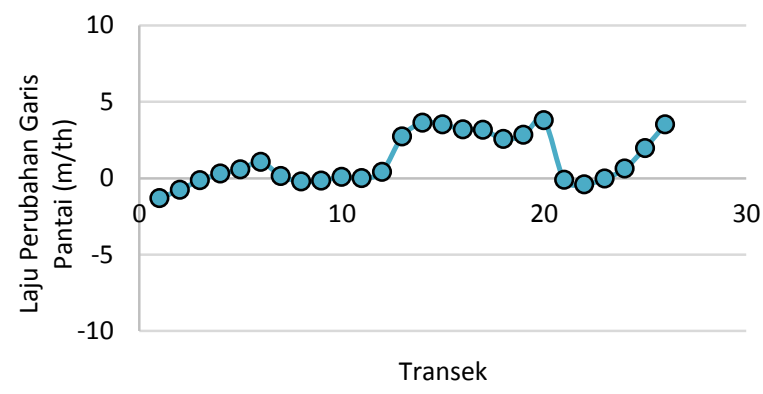

Gambar 7. Laju perubahan garis pantai di Desa Pering

Laju perubahan garis pantai di Desa Keramas pada Gambar 8 keseluruhan transek mengalami akresi. Keseluruhan transek di Desa Keramas berjumlah 20 dengan laju akresi tertinggi terjadi pada transek 2 sebesar $5.3642 \mathrm{~m} /$ th sedangkan laju akresi terendah terjadi pada transek 17 sebesar $1.30575 \mathrm{~m} / \mathrm{th}$.

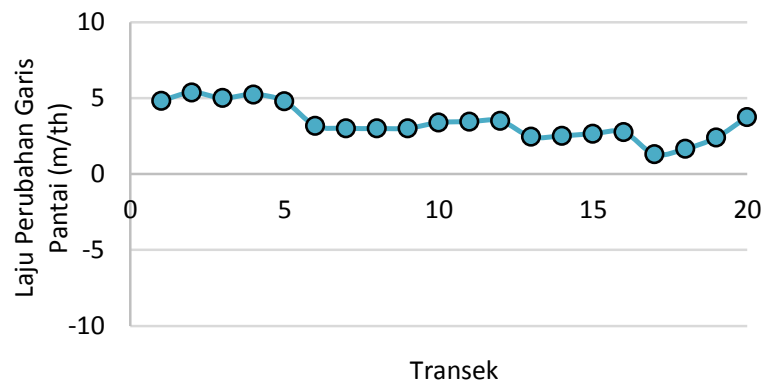

Gambar 8. Laju perubahan garis pantai di Desa Keramas

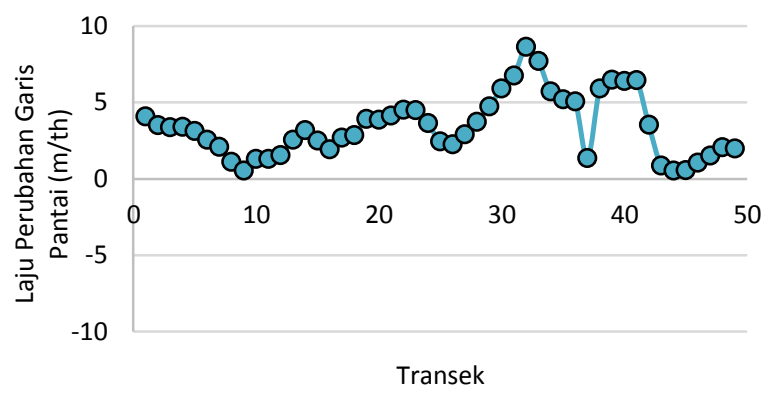

Gambar 9. Laju perubahan garis pantai di Desa Medahan 
Laju perubahan garis pantai di Desa Medahan pada Gambar 9 menunjukkan adanya perubahan akibat akresi. Akresi terjadi pada keseluruhan transek dengan total 49 transek. Laju akresi tertinggi terjadi pada transek ke-32 sebesar 8.60745 $\mathrm{m} / \mathrm{th}$, sedangkan terendah terjadi pada transek ke44 sebesar $0.050965 \mathrm{~m} / \mathrm{th}$.

Laju perubahan garis pantai di Desa Lebih yang ditunjukkan oleh Gambar 10, terdapat akresi dan erosi. Transek yang berjumlah 21 di Desa Lebih, perubahan garis pantai akibat akresi terjadi pada transek ke-1 sampai ke-3, transek ke-14 dan ke-15, transek ke-17 sampai ke-21. Perubahan garis pantai akibat erosi terjadi pada transek ke-4 sampai ke-13, dan transek ke-16. Laju akresi tertinggi terjadi pada transek ke-2 sebesar 3.11945 $\mathrm{m} / \mathrm{th}$, sedangkan laju erosi tertinggi terjadi pada transek ke-5 sebesar $1.83955 \mathrm{~m} / \mathrm{th}$.

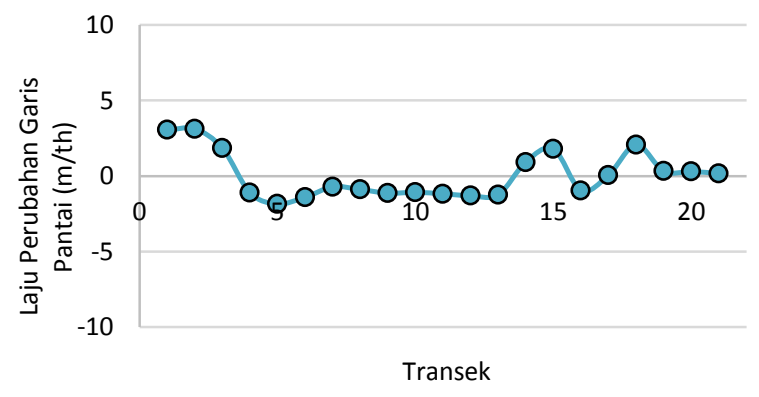

Gambar 10. Laju perubahan garis pantai di Desa Lebih

Laju perubahan garis pantai di Desa Tulikup yang ditunjukkan oleh Gambar 11 keseluruhan mengalami erosi dari total 21 transek. Laju erosi terendah terjadi pada transek ke-3 sebesar 0.99515 $\mathrm{m} / \mathrm{th}$. Laju erosi tertinggi terjadi pada transek ke-12 sebesar $3.39845 \mathrm{~m} /$ th.

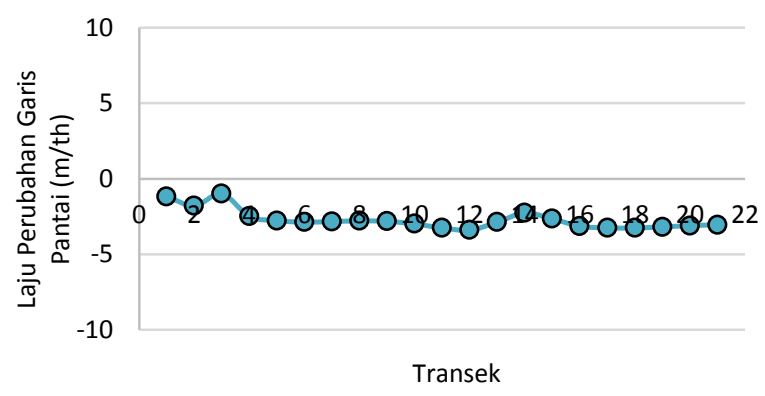

Gambar 11. Laju perubahan garis pantai di Desa Tulikup

Laju perubahan garis pantai di Desa Negari yang ditunjukkan oleh Gambar 12, keseluruhan transek mengalami perubahan akibat erosi. Laju erosi terendah terdapat pada transek ke-13 sebesar $0.88705 \mathrm{~m} / \mathrm{th}$. Sedangkan, laju erosi tertinggi terdapat pada transek ke-6 sebesar $3.09155 \mathrm{~m} / \mathrm{th}$.

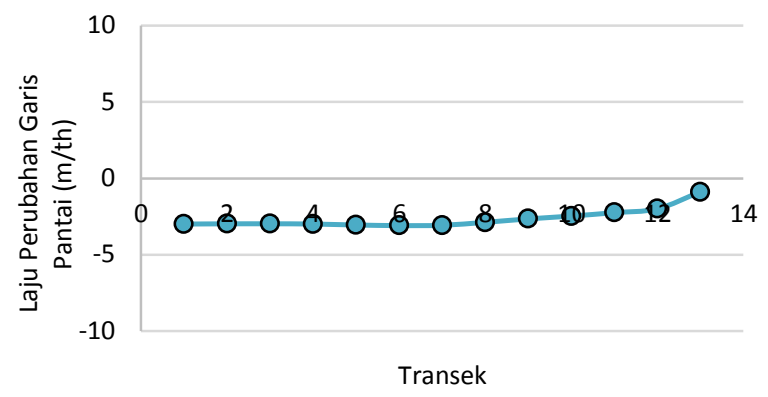

Gambar 12. Laju perubahan garis pantai di Desa Negari

Laju perubahan garis pantai di Desa Takmung pada Gambar 13 menunjukkan adanya perubahan yang sama dengan Desa Negari yaitu akibat erosi. Perubahan garis pantai akibat erosi terdapat pada seluruh transek yaitu 34 transek. Laju perubahan akibat erosi terendah terdapat pada transek ke-34 sebesar $2.0818 \mathrm{~m} / \mathrm{th}$. Laju erosi tertinggi terdapat pada transek ke-26 sebesar $4.18365 \mathrm{~m} / \mathrm{th}$.

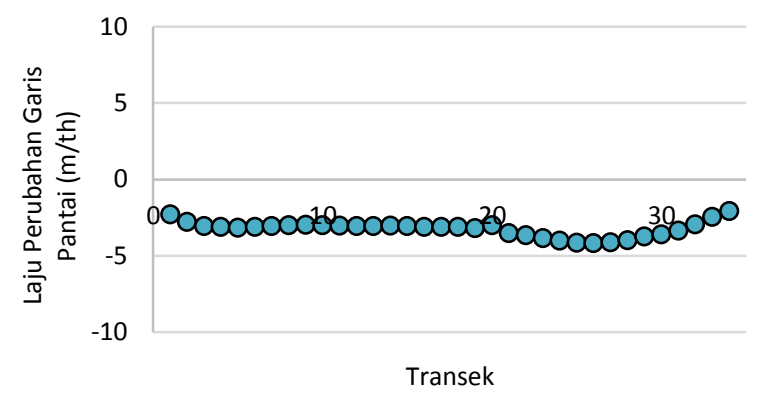

Gambar 13. Laju perubahan garis pantai di Desa Takmung

Laju perubahan garis pantai di Desa Satra pada Gambar 14 diakibatkan oleh adanya erosi. Desa Satra memiliki pantai yang tidak terlalu panjang, sehingga hanya bisa dibuatkan tiga buah transek. Laju erosi pada transek ke-1 adalah $-1.76385 \mathrm{~m} / \mathrm{th}$, transek ke-2 adalah $1.55295 \mathrm{~m} / \mathrm{th}$, dan transek ke-3 adalah $1.40975 \mathrm{~m} / \mathrm{th}$.

Laju perubahan garis pantai di Desa Tojan pada Gambar 15 menunjukkan adanya perubahan garis pantai akibat erosi dan akresi, namun dominan diakibatkan oleh adanya erosi. Perubahan garis pantai akibat akresi hanya terjadi pada transek ke2 dengan laju akresi $1.62525 \mathrm{~m} / \mathrm{th}$. Perubahan garis pantai akibat erosi terjadi mulai pada transek ke-1, transek ke-3 sampai transek ke-17. Laju erosi terendah terjadi pada transek ke-17 sebesar 0.04305 
$\mathrm{m} / \mathrm{th}$, sedangkan laju erosi tertinggi terjadi pada transek ke-12 sebesar $2.1256 \mathrm{~m} / \mathrm{th}$.

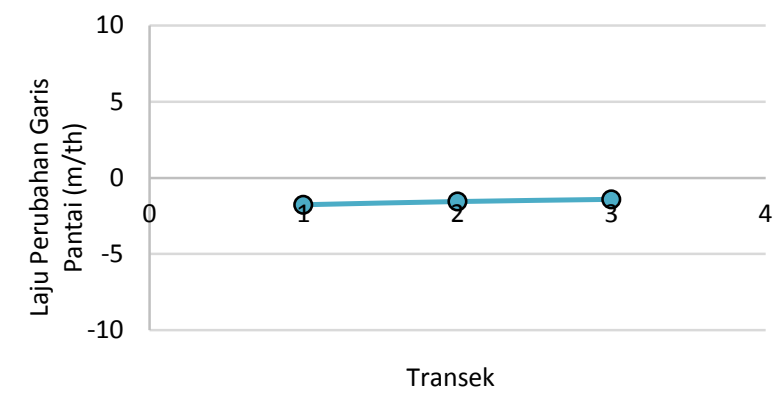

Gambar 14. Laju perubahan garis pantai di Desa Satra

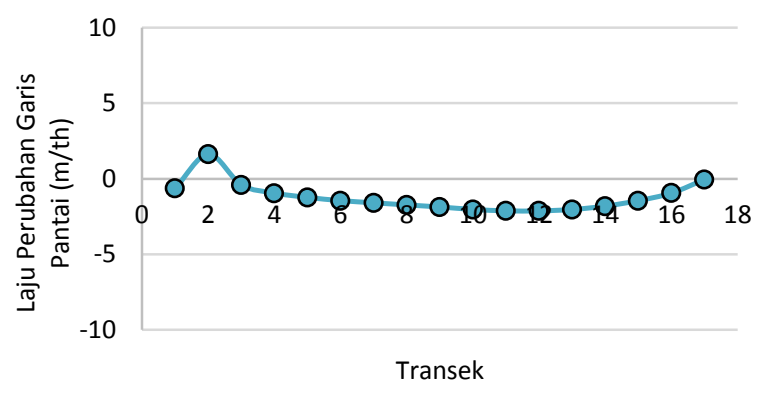

Gambar 15. Laju perubahan garis pantai di Desa Tojan

Laju perubahan garis pantai di Desa Gelgel pada Gambar 16 menunjukkan adanya akresi dan erosi. Perubahan garis pantai akibat akresi terjadi pada transek ke-1 sampai ke-3 dengan laju akresi terendah terjadi pada transek ke-3 sebesar 0.17245 $\mathrm{m} /$ th, sedangkan tertinggi terjadi pada transek ke-1 sebesar $1.1588 \mathrm{~m} /$ th. Perubahan garis pantai akibat erosi terjadi mulai dari transek ke-4 sampai ke-25. Laju erosi terendah terjadi pada transek ke-11 sebesar $0.11645 \mathrm{~m} / \mathrm{th}$, sedangkan tertinggi terjadi pada transek ke-20 sebesar $4.46825 \mathrm{~m} / \mathrm{th}$.

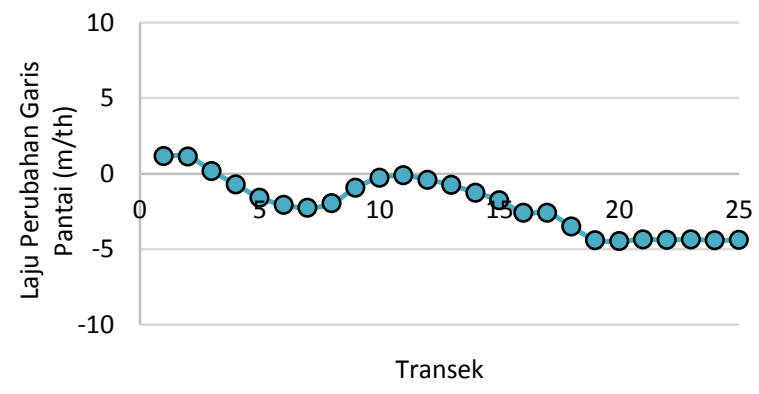

Gambar 16. Laju perubahan garis pantai di Desa Gelgel

Laju perubahan garis pantai di Desa Jumpai yang ditunjukkan oleh Gambar 17, keseluruhan diakibatkan oleh erosi. Dari total 26 transek di
Desa Jumpai, transek ke-20 merupakan transek dengan laju erosi teringgi yaitu $8.8795 \mathrm{~m} / \mathrm{th}$. Laju erosi terendah terdapat pada transek ke- 5 sebesar $2.4721 \mathrm{~m} / \mathrm{th}$.

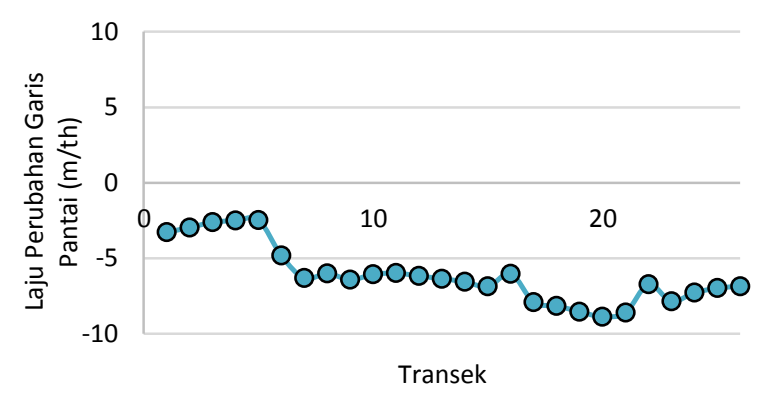

Gambar 17. Laju perubahan garis pantai di Desa Jumpai

Laju perubahan garis pantai di Desa Tangkas keseluruhan transek mengalami erosi. Perubahan garis pantai akibat erosi sangat bervariasi berdasarkan Gambar 18. Laju perubahan garis pantai akibat erosi terendah terjadi pada transek ke-21 sebesar $1.1282 \mathrm{~m} / \mathrm{th}$. Laju erosi tertinggi terjadi pada transek ke-3 sebesar $7.86105 \mathrm{~m} / \mathrm{th}$.

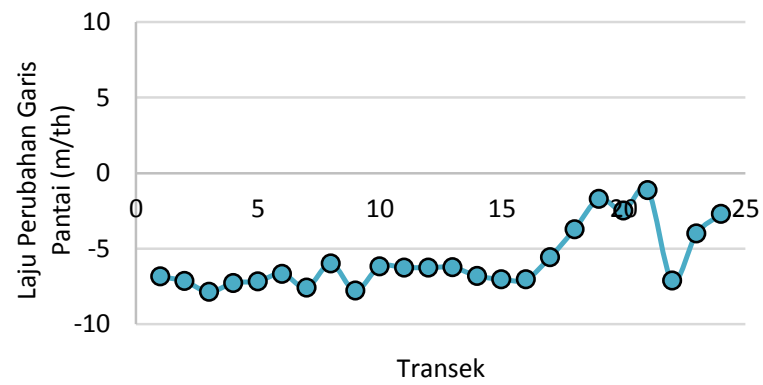

Gambar 18. Laju perubahan garis pantai di Desa Tangkas

Laju perubahan garis pantai di Desa Gunaksa sama dengan Desa Tangkas yaitu diakibatkan oleh erosi (Gambar 19). Total transek yang digunakan untuk perhitungan laju perubahan garis pantai di Desa Gunaksa adalah 13 transek. Laju perubahan garis pantai akibat erosi terendah terjadi pada transek 5 sebesar $7.97145 \mathrm{~m} /$ th. Laju erosi tertinggi terjadi pada transek 1 sebesar $3.58185 \mathrm{~m} / \mathrm{th}$.

Kampung Islam Kusamba memiliki pantai yang tidak terlalu panjang, sehingga total transek yang digunakan untuk perhitungan laju perubahan garis pantai adalah 5 transek. Laju perubahan garis pantai di Kampung Islam Kusamba terjadi akibat akersi dan erosi. Perubahan akibat akresi terjadi pada transek 4 dan transek 5 dengan laju akresi tertinggi terjadi pada 
transek 4 sebesar $1.48705 \mathrm{~m} / \mathrm{th}$, sedangkan terendah terjadi pada transek 5 sebesar $1.4006 \mathrm{~m} /$ th (Gambar 20). Perubahan garis pantai akibat erosi terjadi pada transek 1 sampai dengan transek 3 . Laju erosi tertinggi terjadi pada transek 2 sebesar $0.6337 \mathrm{~m} / \mathrm{th}$ dan terendah terjadi pada transek 1 sebesar $0.15905 \mathrm{~m} /$ th (Gambar 20).

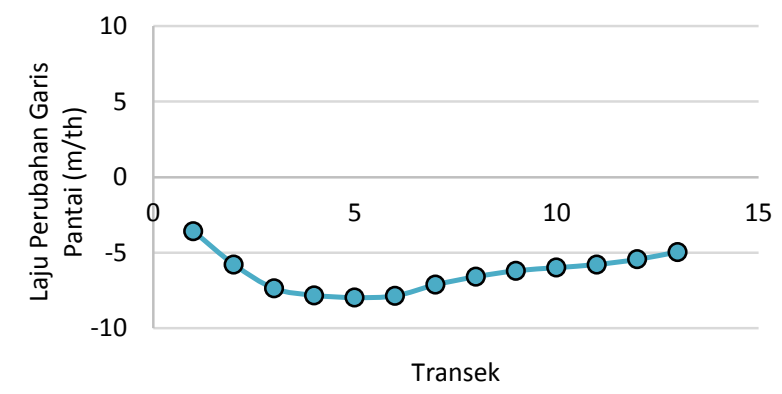

Gambar 19. Laju perubahan garis pantai di Desa Gunaksa

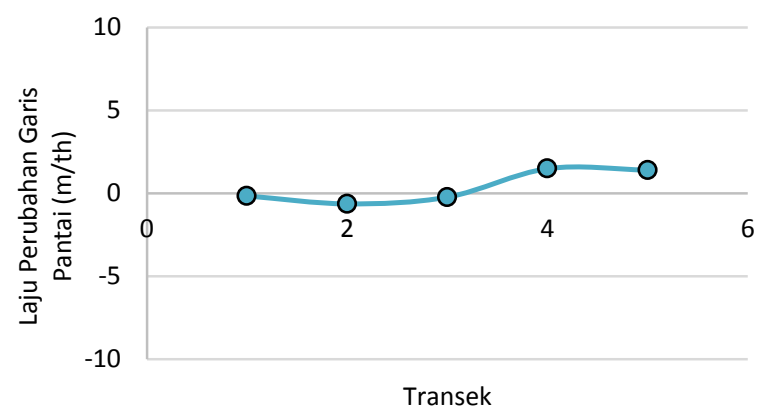

Gambar 20. Laju perubahan garis pantai di K.I Kusamba

Laju perubahan garis pantai di Desa Kusamba pada Gambar 21 menunjukkan adanya perubahan akibat akresi dan erosi yang hampir berimbang. Perubahan garis pantai akibat adanya erosi ditunjukkan oleh transek ke-1 sampai ke-19, transek ke-22, transek ke-30, transek ke-42, dan transek ke-48 sampai ke-51. Laju erosi tertinggi terjadi pada transek ke-1 yaitu $4.6313 \mathrm{~m} / \mathrm{th}$, sedangkan terendah terjadi pada transek ke-30 yaitu $0.0099 \mathrm{~m} / \mathrm{th}$. Perubahan garis pantai akibat akresi ditunjukkan oleh transek ke-20 dan ke-21, transek ke-23 sampai ke-29, transek ke-31 sampai ke-41, transek ke-43 sampai ke-47. Laju akresi tertinggi terjadi pada transek ke-40 sebesar 2.68785 $\mathrm{m} / \mathrm{th}$, sedangkan terendah terjadi pada transek ke47 sebesar $0.161685 \mathrm{~m} / \mathrm{th}$.

Perubahan garis pantai di Desa Pesinggahan tiap transek mengalami fluktuasi yang berbedabeda seperti ditunjukkan oleh Gambar 22. Perubahan garis pantai di Desa Pesinggahan menunjukkan adanya akresi dan erosi. Perubahan akibat akresi terjadi pada beberapa transek yaitu transek ke-3 sampai ke-9, transek 13 sampai ke-15, transek ke-19, transek ke-26, transek ke-39, transek ke-44 dan ke-45. Laju akresi tertinggi terjadi pada transek ke-4 yaitu $1.3747 \mathrm{~m} / \mathrm{th}$, sedangkan terendah terjadi pada transek ke-19 yaitu 0.09675 $\mathrm{m} / \mathrm{th}$.

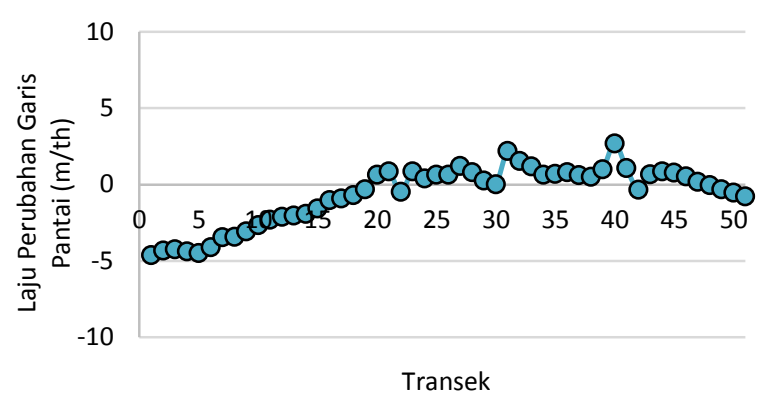

Gambar 21. Laju perubahan garis pantai di Desa Kusamba

Perubahan garis pantai akibat erosi terjadi pada transek ke-1 dan ke-2, transek ke-10 sampai ke-12, transek 16 sampai ke-18, transek 20 sampai ke-25, transek ke-27 sampai ke-34, transek ke-35 sampai ke-38, transek ke-40 sampai ke- 43 , serta transek ke46. Laju erosi tertinggi terjadi pada transek ke-38 yaitu $1.44015 \mathrm{~m} / \mathrm{th}$, sedangkan terendah terjadi pada transek ke-35 yaitu $0.0162 \mathrm{~m} / \mathrm{th}$.

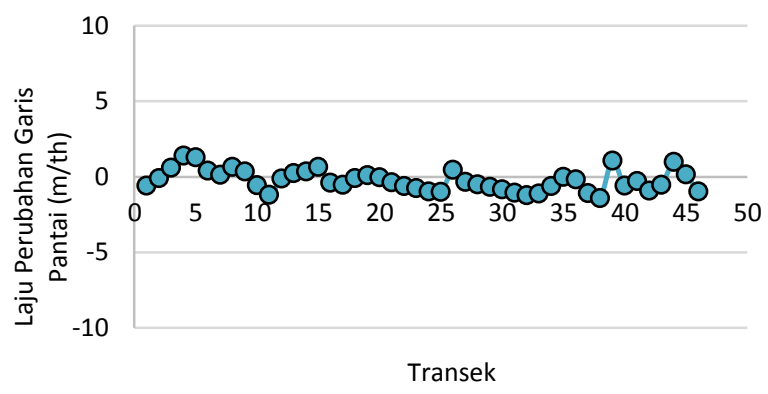

Gambar 22. Laju perubahan garis pantai di Desa Pesinggahan

Fluktuasi perubahan garis pantai akibat dari erosi dan akresi di lokasi penelitian bisa disebabkan oleh beberapa faktor diantaranya faktor dari daratan seperti adanya muara sungai (Faradila et al, 2017) serta pengaruh pasang surut.

Pengaruh pasang surut terhadap ekstraksi garis pantai dari citra Landsat pada penelitian ini bisa dilihat dengan membandingkan posisi revertment atau dinding pantai yang sudah terpasang di beberapa lokasi penelitian. Posisi revertment pada 
penelitian ini diasumsikan sebagai garis pantai sebenarnya di lapangan dan jarak revertment dengan garis pantai hasil interpretasi citra Landsat dijadikan sebagai nilai kesalahan akibat kondisi pasang surut pada saat perekaman citra Landsat. Kondisi pasang surut yang digunakan sebagai perbandingan adalah pasang surut pada waktu perekaman citra Landsat yang digunakan dalam ektraksi garis pantai.

Penelitian ini menggunakan pasang surut pada saat perekaman citra Landsat 8 tahun 2015 sebagai perbandingan jarak dengan revertment, karena keterbatasan informasi terkait pembangunan revertment tersebut. Kondisi air laut pada saat perekaman citra Landsat 8 tahun 2015 adalah pasang menuju surut. Sehingga, dapat diasumsikan terdapat jarak antara garis pantai hasil ekstraksi Landsat 8 dengan revertment. Posisi revertment diambil menggunakan tracking GPS kemudian dibandingkan dengan garis pantai hasil interpretasi Landsat untuk mendapatkan perbedaan jaraknya. Posisi revertment di lokasi penelitian ditunjukkan oleh Gambar 23.
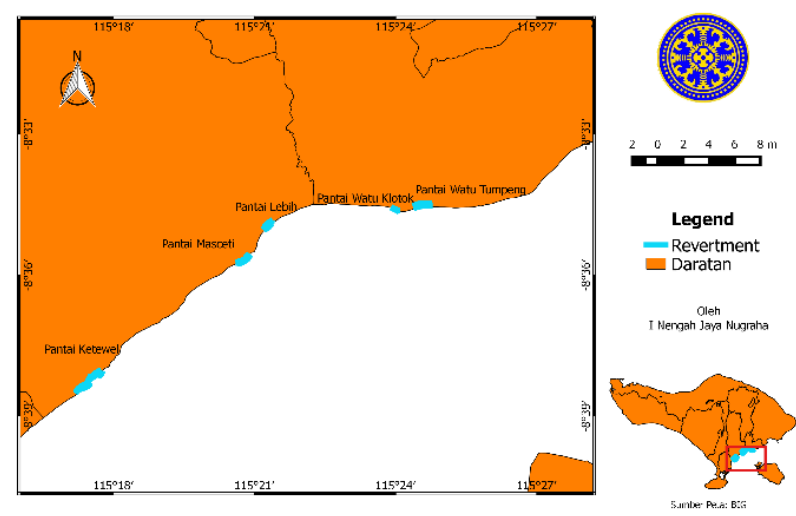

Gambar 23. Posisi revertment di lokasi penelitian

Posisi revertment berdasarkan Gambar 23, yang sudah terpasang terletak di pantai Watu Tumpeng, pantai Watu Klotok, pantai Lebih, pantai Masceti, dan pantai Ketewel. Jarak rata-rata revertment dengan garis pantai hasil interpretasi citra pada kondisi air laut surut ditunjukkan oleh Tabel 2.

Jarak garis pantai citra Landsat 8 dengan revertment pada kondisi surut yang ditunjukkan oleh Tabel 2, terlihat adanya jarak antara revertment dengan garis pantai hasil ekstraksi Landsat 8. Garis pantai hasil ekstraksi Landsat 8 tahun 2015 memiliki jarak dengan revertment masing-masing di Pantai Ketewel 24.274 meter, Pantai Masceti 54.420 meter, Pantai Lebih 9.203 meter, Pantai Watu Klotok 21.168 meter, dan Pantai Watu Tumpeng 20.703 meter. Perbedaan jarak garis pantai hasil interpretasi citra Landsat 8 dengan revertment seperti pada Tabel 2 menunjukkan adanya pengaruh kondisi pasang surut terhadap garis pantai yang diinterptretasikan oleh citra Landsat.

\section{Tabel 2}

Jarak rata-rata revertment dengan garis pantai citra Landsat

\begin{tabular}{llc}
\hline No & Posisi Revertment & $\begin{array}{c}\text { Jarak Garis Pantai dari } \\
\text { Landsat dengan } \\
\text { Revertment (meter) }\end{array}$ \\
\hline 1 & Pantai Ketewel & 24.274 \\
2 & Pantai Masceti & 54.420 \\
3 & Pantai Lebih & 9.203 \\
4 & Pantai Watu Klotok & 21.168 \\
5 & Pantai Watu Tumpeng & 20.703 \\
\hline
\end{tabular}

\section{Simpulan}

Hasil analisis tumpang susun mengidentifikasi garis pantai di Kabupaten Gianyar dan Klungkung mengalami perubahan dengan laju yang berbedabeda setiap desa. Laju perubahan garis pantai di Kabupaten Gianyar akibat akresi diantara 0.5096 $8.6074 \mathrm{~m} / \mathrm{th}$, sedangakn akibat akresi diantara 3.7343 sampai $-1.3201 \mathrm{~m} / \mathrm{th}$. Laju perubahan garis pantai di Kabupaten Klungkung akibat akresi diantara 0.6337 - $2.6875 \mathrm{~m} / \mathrm{th}$, sedangkan akibat erosi diantara -8.8795 sampai $-0.8833 \mathrm{~m} / \mathrm{th}$.

Brdasarkan hasil penelitian ini, perlu adanya penelitian yang membandingkan perubahan garis pantai pada kondisi pasang dan kondisi surut untuk mendapatkan perubahan garis pantai yang mewakili kondisi tersebut.

\section{Ucapan terimakasih}

Penulis mengucapkan terimakasih kepada pihak penyedia Citra Satelit Landsat secara Online (United State of Geospatial Survey). Penulis juga mengucapkan terimakasih kepada peneliti di Laboratorium GIS dan Remote Sensing Fakultas Kelauatan dan Perikanan Universitas Udayana karena telah banyak membantu penulis dalam hal pengambilan data. 


\section{Daftar Pustaka}

Wihardandi, A. (2012). BLH Bali: 48 Pantai di Bali Alami Erosi Akut. [online], (http://www.mongabay.co.id/ 2012/05/30/blh-bali-48-pantai-di-bali-alami-erosiakut/), [diakses: 12 Mei 2016]

Alesheikh, A. A., Ghorbanali, A., \& Nouri, N. (2007). Coastline change detection using remote sensing. International Journal of Environmental Science $\mathcal{E}$ Technology, 4(1), 61-66.

Arthayasa, P.(2014). Pantai Selatan Klungkung Alami Abrasi. [online] (http://bali.antaranews.com/berita/ 64805/pantai-selatan-klungkung-alami-abrasi.) [diakses: 10 Mei 2016]

Pemprov Bali. (2009). Peraturan Daerah Provinsi Bali Nomor 6 Tahun 2009 Tentang Rencana Pembangunan Jangka Panjang Daerah (RPJPD Provinsi Bali Tahun 2005-2025. Pemerintah Daerah Provinsi Bali.

Boak, E. H., \& Turner, I. L. (2005). Shoreline Definition and Detection: A Review. Journal of Coastal Research, 21(4), 688-703.

Church, J. A., Clark, P. U., Cazenave, A., Gregory, J. M., Jevrejeva, S., Levermann, A., Merrifield, M. A., Milne, G. A., Nerem, R. S., Nunn, P. D., Payne, A. J., Pfeffer, W. T., Stammer, D. \& Unnikrishnan, A. S. (2013). Climate change 2013: the physical science basis. Contribution of Working Group I to the Fifth Assessment Report of the Intergovernmental Panel on Climate Change. Sea level change, 1137-1216.

Faradila, C., Setiawan, I., \& Miswar, E. (2017). Analisis Garis Pantai Ladong Aceh Besar Tahun 2010-2015 dengan menggunakan Sistem Informasi Geografis. Journal of Marine and Aquatic Science, 3(1), 84-90.

Fraser, R. H., Olthof, I., Carrière, M., Deschamps, A., \& Pouliot, D. (2011). Detecting long-term changes to vegetation in northern Canada using the Landsat satellite image archive. Environmental Research Letters, 6(4), 045502.

Gregory, J. (2013). Climate Change 2013: The Physical Science Basic Working Group I Contribution to the IPCC Fifth Assessment Report Projections of sea level rise. [online] (http://www.ipcc.ch/pdf/unfccc/cop19/3_ gregory13sbsta.pdf). [diakses: 12 Mei 2016].

Hansen, M. C., \& Loveland, T. R. (2012). A review of large area monitoring of land cover change using Landsat data. Remote sensing of Environment, 122, 6674 .

Hereher, M. E. (2011). Mapping coastal erosion at the Nile Delta western promontory using Landsat imagery. Environmental Earth Sciences, 64(4), 11171125.

Hidayah, R., \& Dwito, H. (2012). Analisa Perubahan Garis Pantai Jasri, Kabupaten Karangasem Bali. Jurnal Teknik Pomits, 1(1), 1-7.

Kaliraj, S., Chandrasekar, N., \& Magesh, N. S. (2015). Evaluation of coastal erosion and accretion processes along the southwest coast of Kanyakumari, Tamil Nadu using geospatial techniques. Arabian Journal of Geosciences, 8(1), 239-253.

Kelley, J., Hobgood, J., Bedford, K., \& Schwab, D. (1998). Generation of Three-Dimensional Lake Model Forecasts for Lake Erie. American Meteorological Society, 13, 659-687.

KKP. (2014). Undang-undang Tentang Perubahan Atas Undang-Undang Nomor 27 Tahun 2007 Tentang Pengelolaan Wilayah Pesisir dan Pulau-pulau Kecil. Jakarta, Indonesia: Kementrian Kelautan dan Perikanan.

Ottinger, M., Kuenzer, C., Liu, G., Wang, S., \& Dech, S. (2013). Monitoring land cover dynamics in the Yellow River Delta from 1995 to 2010 based on Landsat 5 TM. Applied Geography, 44, 53-68.

Purnaditya, Dharma, S., \& Dirgayusa, P. (2007). Prediksi perubahan garis pantai nusa dua dengan One Line Model. Jurnal Ilmiah Infrastruktur Teknik Sipil.1-8.

Putra, A., Husrin, S., \& Ridwan, N. H. H. (2014). Analisa Perubahan Garis Pantai Di Pesisir Timur Laut Bali Dengan Menggunakan Dataset Penginderaan Jauh (Studi Kasus Lokasi Situs Kapal Usat Liberty, Tulamben). Dalam Seminar Nasional Kelautan 2014 Balai Penelitian dan Observasi Laut: Sistem Observasi Laut dan Pemanfaatannya untuk Pembangunan Kelautan dan Perikanan di Indonesia. Jemrana, Indonesia, 14 Oktober 2014 (pp. 143-159).

Roy, D. P., Wulder, M. A., Loveland, T. R., Woodcock, C. E., Allen, R. G., Anderson, M. C., Helder, D., Irons, J. R., Johnson, D. M., Kennedy, R., Scambos, T. A., Schaaf, C. B., Schott, J. R., Sheng, Y., Vermote, E. F., Belward, A. S., Bindschadler, R., Cohen, W. B., Gao, F., Hipple, J. D., Hostert, P., Huntington, J., Justice, C. O., Kilic, A., Kovalskyy, V., Lee, Z. P., Lymburner, L., Masek, J. G., McCorkel, J., Shuai, Y., Trezza, R., Vogelmann, J., Wynne, R. H., \& Zhu, Z. (2014). Landsat-8: Science and product vision for terrestrial global change research. Remote sensing of Environment, 145, 154-172.

Tarigan, M. S. (2007). Perubahan garis pantai di wilayah pesisir perairan cisadane, provinsi banten. Makara Sains 11(1), 49-55.

(C) 2017 by the authors; licensee Udayana University, Indonesia. This article is an open access article distributed under the terms and conditions of the Creative Commons Attribution license (http://creativecommons.org/licenses/by/3.0/). 